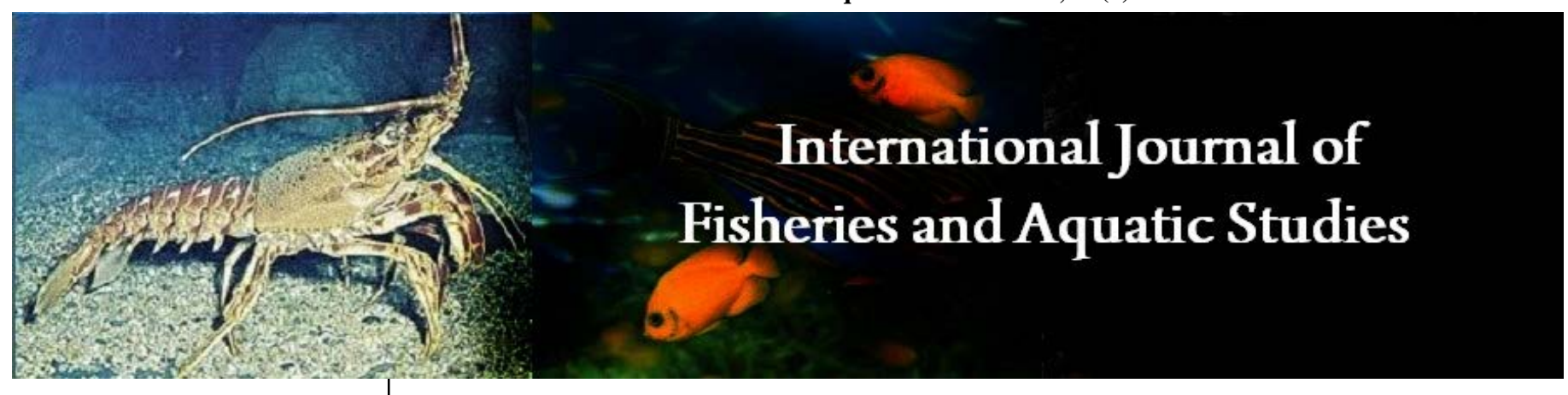

E-ISSN: 2347-5129

P-ISSN: 2394-0506

(ICV-Poland) Impact Value: 5.62

(GIF) Impact Factor: 0.549

IJFAS 2022; 10(1): 33-37

(C) 2022 IJFAS

www.fisheriesjournal.com

Received: 12-11-2021

Accepted: 15-12-2021

\section{Prem Timalsina}

National Fishery Research

Centre, Godawari, Lalitpur, Nepal

\section{Bhuwan Gurung}

National Fishery Research

Centre, Godawari, Lalitpur,

Nepal

\section{Rojina Thapa}

National Fishery Research

Centre, Godawari, Lalitpur,

Nepal

Prakash Kunwor

National Fishery Research

Centre, Godawari, Lalitpur,

Nepal

Asha Rayamajhi

National Fishery Research

Centre, Godawari, Lalitpur,

Nepal

\section{Neeta Pradhan}

National Fishery Research

Centre, Godawari, Lalitpur,

Nepal

Mahendra Bhandari

Fisheries Research Station,

Trishuli, Nepal

\section{Suraj Singh}

Rainbow Trout Fishery Research

Station, Dhunche, Nepal

\section{Anup Sharma}

National Fishery Research

Centre, Godawari, Lalitpur,

Nepal

\section{Tail and fin rot disease and antibiotics resistance pattern in major rainbow trout farms of Nepal}

\author{
Prem Timalsina, Bhuwan Gurung, Rojina Thapa, Prakash Kunwor, Asha \\ Rayamajhi, Neeta Pradhan, Mahendra Bhandari, Suraj Singh and Anup \\ Sharma
}

DOI: https://doi.org/10.22271/fish.2022.v10.i1a.2628

\section{Abstract}

Tail and fin rot is one of the most economically important disease throughout the world. Occurrence of tail and fin rot and emergence of antibiotic resistance in trout farming has mandated extensive survey, characterization of dominant causative agents followed by screening of effective antibiotics. In present study, predominant fin and tail rot causing bacterial pathogens were isolated from samples collected from fifteen rainbow trout farms of major trout pocket areas i.e. Rasuwa, Nuwakot, Dhadhing, Sindhupalchowk, Lalitpur and Kaski districts of Nepal. All the isolates were further tested for pathogenicity, which showed virulence in fancy carp (Cyprinus carpio haematopterus). Pseudomonas spp and vibrio spp showed more virulence. Antibiotic susceptibility test revealed that all the commonly used antibiotics (Amoxicillin, Azithromycin, Neomycin, Oxytetracycline and Streptomycin) were completely resistant. Among presently used antibiotics, Cephalexin was resistance in all the farms while Doxycycline was found completely resistant in two farms and Moxifloxacin was effective in general. Positive correlation between disease occurrence and water parameters were observed among various trout farms. Lack of knowledge regarding use of antibiotics, development of multidrug resistance bacteria and downstream effect of antibiotics used in trout farms was observed among farm's owner and farmers, implicating a need to develop an effective protocol in fresh water aquaculture in Nepal.

Keywords: Rainbow trout, tail and fin rot, pathogenicity, antibiotic, resistance

\section{Introduction}

Water availability and current trend of commercial trout farming trends suggest that Nepal could be one of the lead Trans-Himalayan countries for mountainous cold water aquaculture fish rainbow trout, especially where other agriculture activities are not feasible (Sharma 2008; Gurung TB, Wagle SK, Nepal AP, and Lamsal GP, 2017) ${ }^{[35,26]}$. There are 120 farms producing more than 551 metric tons of rainbow trout in Nepal (NFRC, 2021) ${ }^{\text {[27] }}$. These reasons have attributed to welfare of farmed fish with increased attention in public perception with hind sight of production efficiency, quality and quantity (Broom, 1998; Southgate and Wall, 2001; FSBI, 2002) ${ }^{[6,37,14]}$. Tail and fin rot is one of the major trout bacterial diseases (Larmoyeux and Piper 1971; Faruk, Alam, Sarker and Kabir, 2004, Rayamajhi 1998) ${ }^{[22,12,30]}$ and fin Damage in rainbow trout farms is regarded as operational and welfare indicator of trout farms (Ellis, Oidtmann, St-Hilaire, Turnbull, North B, MacIntyre et al. 2008, Ellis, Hoyle, Oidtmann, Turnbull, Jacklin, and Knowles, 2009; RSPCA 2014) ${ }^{[10,11,34]}$. Higher stocking density with decreased food utilization efficiency and environmental contaminants has been reported to be directly correlated with increase in fin and tail rot (Kindschi, 1987; Jorgensen, Christiansen and Jobling, 1993, Ellis, North, Scott, Bromage, Porter, and Gadd, 2002, Riley, Tatara and Scheurer, 2005) ${ }^{[21,19,9,33]}$. Occurrence of tail and fin rot has also been reported at low stocking density when fish were intermittently fed (Winfree, Kindschi and Shaw, 1998) [31]. Fish stocking density and under fed trout tend to have impaired immune function (Pickering, Pottinger, Sumpter, Carragher, Le Bail, 1991; Adams, Huntingford, Turnbull, and Beattie, 1998; Dibattista, Levesque, Moon, and Gilmour, 2006) ${ }^{[28,2,8]}$. Previous small scale studies in Nepal have reported tail and fin rot as common chronic disease found in poorly kept trout and often occurs simultaneously with other diseases. (Nepal, Basnet, Lamsal, Joshi and Mulmi, 2002; Rayamajhi and Dhital, 2008; Rayamajhi and Prasad 2010, Jha and Bhujel 2012)

$[26,31,32,18]$

\footnotetext{
Corresponding Author:

Prem Timalsina

National Fishery Research Centre, Godawari, Lalitpur, Nepal
} 
To control the spread of tail and fin rot disease various antibiotics are used (Hernández Serrano, 2005; Miranda, Godoy and Lee, 2018; Rahman, Ferdowsy, Kashem and Foysal, 2010) [16, 24, 29]. Moreover, the resistance pattern of bacterial pathogens reflects the extensive use of antibiotics (Smith, Hiney and Samuelsen, 1994; Bruun, Schmidt, Madsen, and Dalsgaard, 2000) ${ }^{[36,5]}$. Over and misuse of antibiotics, especially when these compounds are routinely used, even in the absence of disease has resulted in antibiotic resistance (Cabello, 2006) ${ }^{[7]}$. In context of Nepal, on farm examination of the samples from the fish health camp carried out in Trishuli and Rasuwa showed that about $48 \%$ trout fry, $26 \%$ fingerlings and $13 \%$ broods samples were infected with tail and fin rot disease despite use of the antibiotics (FRD 2018) ${ }^{[13]}$. In addition, available cross sectional reports also supported similar results on food animals pointing the potential overuse or misuse of antibiotics for therapeutic or sub-therapeutic purposes (Acharya, 2011, Khatiwada, 2012) $[1,20]$. An increase in the number of trout farms in the country, the persistent presence of tail and fin rot disease, and improper use of antibiotics have mandated an extensive survey, characterization of dominant causative agents followed by the screening of effective antibiotics as well as its good management practice. Therefore, the aim of the presence study is to isolate and to screen the disease causing pathogen, its pathogenicity and antibiotics profiling of tail and fin rot disease of rainbow in Nepal.

\section{Materials and Methods}

\section{Farm Survey and Fin Rot Sample Collection}

Semi-structured questionnaire and focal group discussion (FGD), was conducted in 15 farms of trout pocket area during early winter season, December-January 15, 2020 (Rasuwa-3, Nuwakot-3, Dhading-1, Sindhupalchocwk-2, Laitpur-2 and Kaski-4). Each fish farm was assigned with unique name code. From each farm, 5 fin-tail rot disease fish \& asymptotic fish as control were collected for microbiological analysis. Blood Sample was collected in vial containing sterile Brain Heart Infusion Broth whereas; kidney, liver \& fin swabs were collected in sterile swab collector (Himedia).

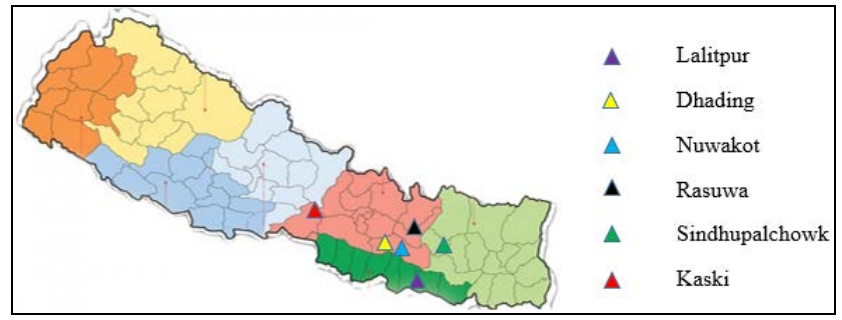

Fig 1: Survey and Sample Collection site

\section{Water Parameter Analysis}

During the Survey, instant water quality parameters (AP500) Dissolved Oxygen, $\mathrm{pH}$, Temperature were recorded from each farm and water $50 \mathrm{ml}$ sample was collected from each farm for Total Ammonical Nitrogen (TAN), Nitrate $\left(\mathrm{NO}_{3}\right)$, Nitrite $\left(\mathrm{NO}_{2}\right)$, Total Alkalinity (TAL) and analyzed at water quality lab of Fisheries Research Division (FRD) Godavari using eXact micro 20 strips kit. Care was taken to record water quality parameters and water sampling at same time period 9:00 am between farms.

\section{Isolation \& Screening of Pathogenic Bacteria}

Isolation, identification of pathogen was conducted disease lab of National Fishery Research Centre, Godavari, Lalitpur. Blood, kidney liver and fin swab samples were enriched on Brain Heart Infusion Broth (BHI) broth at $37{ }^{\circ} \mathrm{C}$ for $24 \mathrm{hrs}$. For the selective isolation of suspected pathogen, enriched sample were streaked on Bile Salt Brilliant Green Starch Agar at $30{ }^{\circ} \mathrm{C}$ for $24 \mathrm{hrs}$, Thiosulfate Citrate Bile Salts Sucrose Agar (TCBS) at $35{ }^{\circ} \mathrm{C}$ for $24 \mathrm{hrs} \&$ Pseudomonas Agar Base with CFC supplement at $25{ }^{\circ} \mathrm{C}$ for $18-48$ hrs (Himedia) for selective the isolation of Aeromonas, Vibrio and Pseudomonas Spp. respectively. Vibrio Spp. Yellow and blue centered isolated colony on TCBS agar was inoculated sterile Triptic Soya Broth (TSB) for further use. Similarly, starch hydrolyzing colony on Bile Salt Brilliant Green Starch Agar (by using Lugol's Iodine) and Fluorescent Colony under the exposure of UV light on Pseudomonas Agar base was inoculated on TSB for further works

\section{Pathogenicity test of isolated organism}

In each 3 Aquarium (15 L), five fancy carps of $1 \mathrm{~g}$ size was injected intra-dermally with $0.01 \mathrm{ml}$ freshly culture pathogen $\left(10^{-4}\right.$ fold) at the base of dorsal fin. Then observed at the interval of 24, 48 and 96 hrs. Fish mortality record were maintained to study effect of inoculated pathogenic bacterium on fish longevity.

\section{Antibiotics sensitivity testing (AST) profiling}

Antibiotics discs with minimum inhibitory concentration (cephalexin $30 \mathrm{mcg}$, doxycycline $30 \mathrm{mcg}$, oxytetracycline 30 mcg, Azithromycin $15 \mathrm{mcg}$, \& Amoxcillin $10 \mathrm{mcg}$ of Himedia. Moxifloxacin 5 mcg, Etrapenum 10 mcg, Neomycin $30 \mathrm{mcg}$, Streptomycin $10 \mathrm{mcg}$ of MAST) with minimum inhibitory concentration (MIC) were tested in vitro using Kirby-Bauer disk diffusion method (Hudzicki, 2016) ${ }^{[17]}$. Fresh culture of each isolates were prepared on Tryptic Soya Broth then Spread on Muller Hilton Agar plates then antibiotics paper disc was placed aseptically and incubated at $30{ }^{0} \mathrm{C}$ for $18-24$ hrs. Diameter of inhibition was measured using digital Vernier caliper.

\section{Result and Discussions}

The study covered the farm from residing as low as 546 masl to the trout farm at 1904 masl where $20 \%$ of the farm were public or government owned and rest were private. Almost all the farm had their own backyard sinking pellet feed mill however during survey period $67 \%$ of these farm had practice of commercially available feed to feed the stock maintained and $33 \%$ had found using farm made pellet feed to fulfill feed requirements. The percentage of farms farm-made pellet feed was found to be driven by seasonal availability and increasing ingredients cost. About $33 \%$ of the farms were found to followed recommended stocking density standards and in rest of the farms the stocking density of fingerlings was more driven by availability of seed during stocking period than to water resources and farm carrying capacity. Moreover, all the farm had optimal water quality requirements within trout culture requirements. Also, all of these farm had Tail and fin rot infected fish indicating the disease prevalent and reoccurring between stock cycles. The details of farm history profile and water quality parameters of surveyed farms is shown in Table 1. 
Table 1: Trout farming Practices and Tail and fin rot history profile

\begin{tabular}{|c|c|c|c|c|c|c|}
\hline Farm Code & District & Elevation (MSL, M) & Feed type & Stocking density no's/sq.m & Economic loss, \% & Type \\
\hline R-Dh-G & Rasuwa & 1823 & Farm-made feed & 120 & 10 & Public \\
\hline R-TB-P1 & Rasuwa & 1904 & Commercial feed & 100 & 12 & Private \\
\hline R-S0-P2 & Rasuwa & 1918 & Commercial feed & 210 & 10 & Private \\
\hline N-TRI-G & Nuwakot & 546 & Farm-made feed & 100 & 15 & Public \\
\hline N-KK-P1 & Nuwakot & 1797 & Farm-made feed & 150 & 10 & Private \\
\hline N-PK-P2 & Nuwakot & 1772 & Farm-made feed & 150 & 12 & Private \\
\hline L-M-P1 & Sindhupalchok & 1573 & Farm-made feed & 150 & 10 & Private \\
\hline S-ML-P1 & Sindhupalchok & 1027 & Farm-made feed & 190 & 12 & Private \\
\hline S-BC-P2 & Lalitpur & 1930 & Commercial feed & 100 & 15 & Public \\
\hline L-Gd-G & Lalitpur & 1530 & Commercial feed & 100 & 9 & Public \\
\hline Po-GH-P1 & Kaski & 1219 & Farm-made feed & 120 & 20 & Private \\
\hline Po-GT-P2 & Kaski & 1359 & Farm-made feed & 175 & 15 & Private \\
\hline Po-MP-P3 & Kaski & 1280 & Commercial feed & 100 & 20 & Private \\
\hline Po-IT-P4 & Kaski & 1222 & Farm-made feed & 120 & 15 & Private \\
\hline D-SG-P1 & Dhadhing & 1167 & Farm-made feed & 120 & 12 & Private \\
\hline
\end{tabular}

During the study, water quality parameters as shown in Table 2 ranged as temperature ( $\mathrm{Tem}^{\circ} \mathrm{C}$ ) 8.7-18.2; dissolved oxygen (Do, ppm) 6.9-10; pH 7.2-9.1; total ammonical nitrogen (TAN, ppm) 0.01-0.039; Nitrite $\left(\mathrm{NO}_{2}\right)$ 0.01-0.51; nitrate (NO, $\mathrm{ppm}$ ) 0.01-0.17; Total hardness (TH, ppm) 15-105 and Total alkalinity (TAL, ppm) 29-111 in infected raceway ponds. These water quality parameters were within the standard of rainbow trout farming. Moreover, from questionnaire survey, it was found that in case of occurrence of fin and tail rot farmers don't follow the standard protocol to control disease, where $20 \%$ of them even do not know about antibiotics and their resistance to bacteria after repetitive use. The nearby agro vet supplier's recommendation was found to be determinant for the drug, and its dose was found exceeding the earlier maximum limit in each subsequent disease emergence fish batch to control the disease. They are using antibiotics haphazardly, and this malpractice is predominantly prevalent. Three species of gram negative bacteria aeromonas, pseudomonas and vibrio spp. have been reported as major causative agents for tail and fin rot disease in trout (Faruk, Alam, Sarker and Kabir, 2004; Manshadi and Assareh, 2014) ${ }^{[12,30]}$.

Table 2: Water quality parameters recorded in different farm during fish sampling

\begin{tabular}{|c|c|c|c|c|c|c|c|c|}
\hline Farm code & $\mathbf{D O}(\mathbf{p p m})$ & $\mathbf{p H}$ & $\left.\mathbf{T e m} \mathbf{(}^{\mathbf{}} \mathbf{C}\right)$ & $\mathbf{T A N} \mathbf{( p p m )}$ & $\mathbf{N O}_{\mathbf{2}} \mathbf{( p p m )}$ & $\mathbf{N O}_{\mathbf{3}} \mathbf{( p p m )}$ & $\mathbf{T H}(\mathbf{p p m})$ & TAL (ppm) \\
\hline R-Dh-G & 8.2 & 8.8 & 11 & 0.01 & 0.28 & 0.17 & 66 & 29 \\
\hline R-TB-P1 & 8.5 & 8.5 & 8.7 & 0.01 & 0.13 & 0.01 & 71 & 32 \\
\hline R-S0-P2 & 7.8 & 8.8 & 9.9 & 0.01 & 0.06 & 0.01 & 19 & 27 \\
\hline N-TRI-G & 9.8 & 8.5 & 12.1 & 0.01 & 0.12 & 0.01 & 75 & 83 \\
\hline N-KK-P1 & 7.7 & 9.1 & 11.6 & 0.021 & 0.36 & 0.05 & 63 & 33 \\
\hline N-PK-P2 & 8.1 & 7.8 & 11.3 & 0.03 & 0.51 & 0.01 & 62 & 32 \\
\hline L-M-P1 & 6.9 & 7.2 & 11.2 & 0.02 & 0.12 & 0.01 & 61 & 29 \\
\hline S-ML-P1 & 7.3 & 7.4 & 11.4 & 0.03 & 0.12 & 0.01 & 15 & 29 \\
\hline S-BC-P2 & 9.6 & 7.6 & 11.3 & 0.028 & 0.12 & 0.01 & 64 & 64 \\
\hline L-Gd-G & 7.9 & 7.8 & 14 & 0.015 & 0.01 & 0.02 & 105 & 96 \\
\hline Po-GT-P2 & 7.7 & 8.3 & 15.1 & 0.04 & 0.49 & 0.01 & 90 & 111 \\
\hline Po-GH-P1 & 7.9 & 8.2 & 14.1 & 0.04 & 0.12 & 0.01 & 69 & 79 \\
\hline Po-MP-P3 & 8.4 & 7.9 & 14.1 & 0.02 & 0.12 & 0.02 & 82 & 100 \\
\hline Po-IT-P4 & 7.2 & 7.9 & 18.2 & 0.015 & 0.32 & 0.01 & 98 & 88 \\
\hline D-SG-P1 & 10 & 8.2 & 15.1 & 0.01 & 0.12 & 0.01 & 95 & 87 \\
\hline
\end{tabular}

*D: Diseased, A: Asymptotic as Control; CN: Cephalexin, DO: Doxycycline, N: Neomycin, Mfx: Moxifloxacin and S: Streptomycin Amx: Amoxicillin, Azm: Azithromycin, ETP: Etrapenum and O: Oxytetracycline

All three organisms were isolated from blood, kidney liver and fin swab of diseased fish (Table 3). Among which aeromonas spp was more common. And $50 \%$ of the asymptotic or control samples from all the 15 farms were also positive for bacteria i.e. those fish samples could have inhabited the dormant tail-fin rot causative pathogens. Isolates from all the samples (diseased and control) were confirmed by biochemical test. Pathogenicity test conformed all the three species were pathogenic as symptoms of erosion of tail and fin was observed in fancy carp fish. With varying degree of pathogenicity. The fish inoculated with vibrio and pseudomonas showed symptoms of fin erosion after 24 hrs of post inoculation which was earlier than aeromonas showing symptoms after 48 hours of post infection. Attempts was made to quantify symptoms on a scale of $0-8$ to assign a numerical value. The symptom progressed as Normal fin; White lining on edge of caudal fin; White margins disappears as erosion progress; Fin Fringe begins at edges; Fin erodes rapidly to its deep layer; Fin erodes rapidly with rupture of blood vessel; blunt tail with no or lesser fin and final death. The difference in pathogenicity among bacteria was found significant $(\mathrm{p} \leq 0.05)$. The symptoms progressed rapidly in samples inoculated with vibrio followed by pseudomonas and aeromonas bacteria. Moreover, the fish inoculated with vibrio remained alive for 7 days after post inoculation, however, those inoculated with pseudomonas and aeromonas survived for 10 days and 15 days respectively. This indicated that vibrio and pseudomonas incubation period was rapid enough to slow down immune system of the fish making it more virulence whereas there is slow and chronic progression of disease by aeromonas spp. The study on Pathogen and antibiotics resistance profile (Table 3) showed pathogen isolated from all the 15 farms were resistance to Cephalexin, Neomycin, amoxicillin, streptomycin and azithromycin when offered in dose as recommended by NFRC godawari. 
Table 3: Pathogen isolated from different farms and its Antibiotics Resistance Profile

\begin{tabular}{|c|c|c|c|c|c|c|c|}
\hline \multirow{2}{*}{ Name of Farms } & \multicolumn{2}{|c|}{ Aeromonas spp \% } & \multicolumn{2}{|c|}{ Vibrio spp\% } & \multicolumn{2}{|c|}{ Pseudomonas spp\% } & \multirow{2}{*}{ Resistant Antibiotics } \\
\hline & D & A & D & A & D & A & \\
\hline R-TB-P1 & 20 & 15 & 0 & 0 & 25 & 0 & CN, AZM, AMX, S, N \\
\hline R-Dh-G & 33 & 0 & 0 & 0 & 0 & 0 & CN, AZM, AMX, N \\
\hline R-S0-P2 & 20 & 0 & 45 & 5 & 35 & 0 & CN, AZM, AMX, S, N \\
\hline N-TRI-G & 40 & 15 & 10 & 10 & 60 & 25 & CN, AZM, AMX, S, N \\
\hline N-KK-P1 & 50 & 40 & 55 & 40 & 20 & 10 & $\mathrm{CN}, \mathrm{AZM}, \mathrm{AMX}, \mathrm{S}, \mathrm{N}$ \\
\hline N-PK-P2 & 100 & 45 & 100 & 70 & 85 & 45 & DO, MFX, CN, AZM, AMX, S, N,O \\
\hline L-M-P1 & 60 & 55 & 0 & 0 & 85 & 60 & CN, AZM, AMX, S, N, ETP \\
\hline S-ML-P1 & 80 & 75 & 20 & 25 & 28 & 15 & CN, AZM, AMX, S, N, ETP \\
\hline S-BC-P2 & 50 & 30 & 10 & 0 & 25 & 15 & CN, AZM, AMX, S, N \\
\hline L-Gd-G & 0 & 0 & 10 & 10 & 0 & 0 & CN, AZM, AMX, S, N \\
\hline Po-GT-P2 & 70 & 30 & 55 & 30 & 0 & 0 & CN, AZM, AMX, S, N \\
\hline Po-GH-P1 & 55 & 25 & 25 & 15 & 0 & 0 & CN, AZM, AMX, S, N, O \\
\hline Po-MP-P3 & 85 & 50 & 50 & 25 & 20 & 20 & CN, AZM, AMX, S, N, O \\
\hline Po-IT-P4 & 75 & 30 & 55 & 20 & 20 & 0 & CN, AZM, AMX, S, N, O, ETP \\
\hline D-SG-P1 & 25 & 20 & 80 & 45 & 45 & 35 & DO, MFX, CN, AZM, AMX, S, N, O \\
\hline
\end{tabular}

Organisms isolated from private trout farm located in dhadhing, D-SG-P1 and nuwakot, N-PK-P2 were resistant to doxycycline, oxytetracycline, moxifloxacin in addition to the antibiotics those were resistant in all the farms. The fish samples collected from these farms also had relatively high microbial load. The most probable reason for these results according to the field survey was the drug being used intermittently continuous within and across production batches. Downstream farm at Nuwakot, N-PK-P2 showed relatively more antibiotics resistance than its upstream farm N-KK-P1. This could be due to of untreated effluents from the upstream is continuously passed to the downstream resulting in variation in antibiotics residues in raceways. Although correlation between antibiotic uses and development of antibiotics resistance was not reported from the survey, the result represented observable misuse of antibiotics. This may be because sampling was not done during clinical outbreak. In farm no N-KK-P1 and N-PK-P2 prescribed antibiotics Florfenicol, Colistin Sulphate are being extensively used. Co-relation between pathogen load and source of water was also observed. The private farms at Kaski Po-GH-P1, Po-IT-P4 and dhadhng D-SG-P1 have relatively higher microbial load when compared to similar size of other farms along with high water temperature and low dissolved oxygen was low and result is supported by earlier study). This illustrates that lower DO and higher temperature is correlated with higher incidence of tail and fin rot (Ajayi and Okoh, 2013; Mosig and Fallu, 2004) ${ }^{[3,25]}$. There was also co-relation between pathogen load and source of water. The farms located near the warm spring source had more pathogen load than the farms that were water from flowing systems. Amount of dissolved oxygen may be reason that made the fishes in those farm more susceptible to pathogenic attack. That can also be justified by the fact that R-S0-P2 private trout farm, rasuwa which use water diverted from the streams flowing the mountains have low diseased occurrence, even though with high density stocking. AST (Antibiotic Susceptibility Test), supported the idea of most of the current antibiotics in use being resistant against the pathogens. For instance, even broad spectrum of antibiotics like: cephalexin doxycycline has been found possessing resistance.

\section{Conclusion \& Recommendation}

In conclusion, the study reveals that trout farms in surveyed fish pocket areas exhibit significant frequencies of bacteria with low to high level antibiotic resistance. Our results stress the importance of awareness among trout fish farmers in use and misuse of antibiotic along with training to farmers and technical personnel on primary fish health management packages and establishment of mobile diagnostic centers. Furthermore, it highlights the importance of preventive measures in trout farming to minimize the antimicrobial agents as well as their release to effluent water. Further work with increase in sample size, microbial analysis of water for comparison of isolates in inlet and outlet of raceways; molecular characterization of micro flora will help to elucidate the general picture of pathogen and their antibiotics susceptibility pattern nature in trout farms of Nepal.

\section{Acknowledgment}

The authors would like to acknowledge Nepal Agricultural Research Council (NARC) for financial support. We also acknowledge NFRC, Godawari family; in providing timely inputs, support and respective farmers for coordination in carrying out the research.

\section{References}

1. Acharya KR. Antimicrobial Residue and Prevalence of Indicator Bacteria Having Antimicrobial Resistance Isolated From Marketed Poultry in Kathmandu, Nepal. 2011.

2. Adams CE, Huntingford FA, Turnbull JF, Beattie C. Alternative competitive strategies and the cost of food acquisition in juvenile Atlantic salmon (Salmo salar). Aquaculture. 1998;167:17-26.

3. Ajayi O, Okoh A. Bacteriological study of pond water for aquaculture purposes. Journal of Food Agriculture and Environment. 2013.

4. Alanara A, Winberg S, Brannas E, Kiessling A, Hoglund E, Elofsson U. Feeding behaviour, brain serotonergic activity levels, and energy reserves of Arctic char (Salvelinus alpinus) within a dominance hierarchy. Can. J. Zool. 1998;76:212-220.

5. Bruun MS, Schmidt AS, Madsen L, Dalsgaard I. Antimicrobial resistance patterns in Danish isolates of Flavobacterium psychrophilum. Aquaculture. 2000;187(3):201-212.

6. Broom DM. The concept of stress and welfare. Recueil De Medecine Veterinaire. 1988, 715-721.

7. Cabello FC. Heavy use of prophylactic antibiotics in aquaculture: A growing problem for human and animal 
health and for the environment. Environmental Microbiology. 2006;8(7):1137-1144.

8. Dibattista JD, Levesque HM, Moon TW, Gilmour KM. Growth Depression in Socially Subordinate Rainbow Trout Oncorhynchus mykiss: More than a Fasting Effect. Physiological and Biochemical Zoology. 2006;79(4):675687

9. Ellis T, North B, Scott AP, Bromage NR, Porter M, Gadd D. The relationships between stocking density and welfare in farmed rainbow trout. J. Fish Biol. 2002;61(3):493-531.

10. Ellis T, Oidtmann B, St-Hilaire S, Turnbull J, North B, MacIntyre $\mathrm{C}$, et al. Fin erosion in farmed fish. In: Branson E. (Ed.), Fish Welfare. Blackwell, Oxford. 2008, 121-149.

11. Ellis T, Hoyle I, Oidtmann B, Turnbull J, Jacklin TE, Knowles T. Further development of the "Fin Index" method for quantifying fin erosion in rainbow trout. Aquaculture. 2009;289:283-288.

12. Faruk MAR, Alam MJ, Sarker MMR, Kabir MB. Status of fish disease and health management practices in rural freshwater aquaculture of Bangladesh. Pakistan J Biol Sci. 2004;7(12):2092-2098.

13. FRD. Annual Report 2074/75 (2017/18). Fisheries Research Division, NARC, Godawari, Lalitpur, Nepal. 2018.

14. FSBI. Fish Welfare. Breifing Report 2. Fisheries Society of the British Isles, Granta Information systems. 2002. http:// www.le.ac.uk/biology/fsbi/welfare.pdf.

15. Gurung TB, Wagle SK, Nepal AP, Lamsal GP. Rainbow trout (Oncorhynchus mykiss) based mountain aquaculture in Nepal. NJAF. 2017;(3, 4):12-20

16. Hernández Serrano P. Responsible use of antibiotics in aquaculture. Food and Agriculture Organization of the United Nations, Rome. 2005, 2005,110.

17. Hudzicki J. Kirby-Bauer Disk Diffusion Susceptibility Test Protocol. American Society for Microbiology. 2016, $1-16$.

18. Jha DK, Bhujel RC. Incidence of fish diseases and management practices in Nepal. In: Shrestha MK and Pant J (eds.). Small-scale Aquaculture for Rural Livelihoods: Proceedings of the National Symposium on Small-scale Aquaculture for Increasing Resilience of Rural Livelihoods in Nepal. Institute of Agriculture and Animal Science, Tribhuvan University, Rampur, Chitwan, Nepal, and The World Fish Center, Penang, Malaysia. 2012, 191.

19. Jorgensen EH, Christiansen JS, Jobling M. Effects of stocking density on food intake, growth performance and oxygen consumption in Arctic charr (Salvelinus alpinus). Aquaculture. 1993;110(2):191-204.

20. Khatiwada S. Trends in antimicrobial use in food animals of Nepal. (B. V. Sc. and A. H. thesis). Institute of Agriculture and Animal Science (IAAS); Tribhuvan University, Rampur, Nepal. 2012.

21. Kindschi GA. Method for Quantifying Degree of Fin Erosion. The Progressive Fish-Culturist. 1987;49(4):314315.

22. Larmoyeux JD, Piper RG. Reducing eroded fin condition in hatchery trout. U.S. Trout News. 1971;5:8-9.

23. Manshadi AG, Assareh R. Bacterial study of fin rot in brown trout by API20E. Pakistan Journal of Biological Sciences: PJBS, 2014;17(3):434-438.

24. Miranda CD, Godoy FA, Lee MR. Current Status of the
Use of Antibiotics and the Antimicrobial Resistance in the Chilean Salmon Farms. Frontiers in Microbiology. 2018, 1-14.

25. Mosig J, Fallu R. Australian Fish Farmer: A Practical Guide to Aquaculture. Landlinks Press. 2014.

26. Nepal AP, Basnet SR, Lamsal GP, Joshi PL, Mulmi RM. Economics of rainbow trout farming systems in Nepal. In: Petr $\mathrm{T}$ and Swar DB (eds.). Cold Water Fisheries in the Trans-Himalayan Countries. FAO Fisheries Technical Paper No. 431 Rome, FAO. 2002, 376.

27. NFRC. Annual Report 2077/78 (2020/21). National Fishery Research Centre, NARC, Godawari, Lalitpur, Nepal. 2021, 118.

28. Pickering AD, Pottinger TG, Sumpter JP, Carragher JF, Le Bail PY. Effects of acute and chronic stress on the levels of circulating growth hormone in the rainbow trout, Oncorhynchus mykiss. Gen Comp Endocrinol. 1991;83(1):86-93

29. Rahman MM, Ferdowsy H, Kashem MA, Foysal MJ. Tail and Fin Rot Disease of Indian Major Carp and Climbing Perch in Bangladesh. Journal of Biological Sciences. 2010;10(8):800-804.

30. Rayamajhi A. Review on Fish Health Management in Nepal. In: Proceedings of the NARC, National Seminar on Present status of Fisheries Research, Development and Education in Nepal, Natural Water Fisheries Development Project. Nepal Agricultural Research Council (NARC) Japan International Cooperation Agency (JICA). 1998, 119-122.

31. Rayamajhi A, Dhital RR. An evaluation on rainbow trout (Oncorhynchus mykiss) diseases and their control measures in Nepal. In: Gurung TB (ed), Rainbow trout (Oncorhynchus mykiss) farming strategies in Nepal. Proceedings of the workshop on scaling-up of Rainbow trout (Oncorhynchus mykiss) farming strategies in Nepal, Kathmandu, Nepal. 2008, 137.

32. Rayamajhi A, Prasad S. Trout fish disease and parasites and prevention measures. In: Wagle SK, Nepal AP, Rayamajhi A and Pradhan N (eds). Rainbow Trout Fish Farming Technology and Practice (In Nepali). Fisheries Research Division. Nepal Agricutural Research Council, Kathmandu, Nepal. 2010, 117.

33. Riley SC, Tatara CP, Scheurer JA. Aggression and feeding of hatchery-reared and naturally reared steelhead (Oncorhynchus mykiss) fry in laboratory flume and comparison with observation in natural streams. Canadian Journal of Fisheries and Aquatic Sciences. 2005;62(6):1400-1409.

34. RSPCA. RSPCA welfare standards for farmed rainbow trout. Royal Society for the Prevention of Cruelty to Animals, Wilberforce Way, Southwater, Horsham, West Sussex. 2014.

35. Sharma CM. Freshwater fishes, fisheries, and habitat prospects of Nepal. Aquatic Ecosystem Health \& Management. 2008;11(3):289-297.

36. Smith P, Hiney MP, Samuelsen OB. Bacterial resistance to antimicrobial agents used in fish farming: A critical evaluation of method and meaning. Annual Review of Fish Diseases. 1994;4:273-313.

37. Southgate $P$, Wall T. Welfare of farmed fish at slaughter. In Practice. 2001;23(5):277-284.

38. Winfree RA, Kindschi GA, Shaw HT. Elevated Water Temperature, Crowding, and Food Deprivation Accelerate Fin Erosion in Juvenile Steelhead Trout. The Progressive Fish-Culturist. 1998;60(3):192-199. 